\title{
Gönüllü Yönetiminin Önemli Bir Aşaması Olarak Performans Değerlendirme
}

Fethi Güngör ${ }^{1}$

Özet

Sosyal sağlığın korunmasına ve toplumsal gelişmeye önemli katkılar yapan sivil toplum kuruluşları, bütün dünyada kamu ve özel sektörün yanı sıra sosyal hayatta vazgeçilmez üçüncü bir yeni sektör haline gelmiștir. Özellikle dezavantajlı gruplara yönelik sosyal hizmetler sunan ve sayıları günbegün artan STK'ların misyonlarını gerçekleştirebilmeleri etkin hizmetler sunabilmelerine, bu da önemli ölçüde sivil toplum kuruluşlarının en önemli aktörleri olan gönüllülerin verimli istihdamına bağlıdır.

Gönüllülerin üstlendikleri görevleri etkin ve verimli bir şekilde gerçekleştirebilmesi gönüllü yönetiminde sağlanacak başarıyla doğru orantılıdır. Bu bağlamda STK'ların insan servetini oluşturan gönüllülerin yönetiminde performans değerlendirme modeli oluşturmak hem gönüllü, hem STK, hem de hizmet alan kesimler açısından önem kazanmaktadır. Bu tebliğde teorik çerçevenin ardından 360 Derece Performans Değerlendirme modeli değerlendirilerek düzeltilmiş bir versiyonu gönüllü kurulușların kullanımına sunulmaktadır.

Anahtar Kelimeler: Sivil Toplum Kuruluşları, Gönüllülük, Gönüllü Yönetimi, Performans Değerlendirme, 360 Derece Gönüllü Performans Değerlendirme Modeli.

\footnotetext{
${ }^{1}$ Doç. Dr., Yalova Üniversitesi, İktisadi ve İdari Bilimler Fakültesi, Sosyal Hizmet Bölümü,
} fgungor@gmail.com 


\section{Giriş}

Tüm dünyada kamu ve özel sektörün dışında üçüncü bir sektör haline gelen ve gönüllülük prensibiyle hareket eden vakıf, dernek, platform gibi sivil toplum kuruluşları, toplumsal bilincin oluşmasını sağlayan, devletin uzanamadığı ya da yetersiz kaldığı alanlarda insanların ihtiyaçlarını karşılamak amacını taşıyan, dezavantajlı durumdaki insanların haklarını savunma rolünü üstlenen, aynı zamanda dünya barışı bilinci ile uluslararası alanda boy gösteren ve çoğu hizmetlerini maddi beklentisi olmayan gönüllüler aracılığıyla yürüten kuruluşlardır.

Sivil toplum kuruluşlarının ana faaliyetlerini oluşturan gönüllü hareketler için en önemli faktör insan servetidir. 'Gönüllü’ olarak adlandırılan bu insan serveti, herhangi bir sivil toplum kuruluşunda gönüllü faaliyetlere hiçbir beklentisi olmadan katkı sağlayarak toplumsal bir sorumluluğu yerine getirmektedir. Böylelikle gönüllü bireyler, ihtiyaç sahibi insanlara yardım ederek toplum için yararlı olma tatmini kazanmakta ve yapılan bu faaliyetler gönüllüleri mutlu etmekte, kendilerine güvenmelerini ve gönül rahatlığı yaşamalarını sağlamaktadır. Aynı zamanda gönüllüler, sivil toplum kuruluşları açısından; kuruluşların hizmetlerini etkin ve verimli şekilde sunmasında, kurumun sürdürülebilir vasfı kazanmasında ve sosyal sorunların çözümü hususunda büyük rol oynamaktadır.

Gönüllü hareketlerin toplumda daha önemli hale gelmesiyle birlikte gönüllülüğün daha profesyonel ve daha donanımlı olmayı gerekli kılmaya başladığı görülmektedir. Bu durumun nedenlerinden biri, sivil toplum kuruluşlarının hizmet verdiği toplumsal kesimlerin başında oldukça kompleks sorunlara sahip dezavantajlı grupların gelmesidir. $\mathrm{Bu}$ gruplara etkili bir şekilde hizmet sunabilmek ve böylece STK'ların misyonlarını gerçekleştirebilmek için sivil toplum kuruluşlarının en önemli aktörleri olan gönüllülere büyük görevler düşmektedir. Bir diğer neden ise sivil toplum kuruluşlarının sayılarının günden güne artması ve dolayısıyla bu kuruluşlarda çalışan sayılarının da artmasıdır. Bu çalışanlar arasında gönüllüler, faaliyet alanı bakımından toplumun onda birinden fazla yakın büyük bir kitleyi doğrudan etkilemektedir. Dolayısıyla bu kadar geniş bir kitleye kaliteli bir hizmet sunulabilmesi için donanımlı gönüllülere ihtiyaç duyulmaktadır. $\mathrm{Bu}$ 
bağlamda gönüllülerin görevlerini etkin ve eksiksiz bir şekilde gerçekleştirebilmesi için profesyonel gönüllü yönetimine ihtiyaç şiddetle ihtiyaç duyulmaktadır.

Günümüzde dünyada olduğu gibi ülkemizde de sivil toplum kuruluşlarının misyonlarının artması ile birlikte bu gönüllü kuruluşlar daha çok büyümeye ve kurumsallaşmaya başlamıştır. Fakat büyüyen ve yaygınlaşan STK'larda çeşitli yönetim sorunları ortaya çıkmaktadır. Bu sorunlar STK'ların çoğunlukla amatörce yönetilmesinden kaynaklanmaktadır (Coşkun, 2008: 5). Üçüncü sektörde yaşanan yönetim sorunlarının önemli bir sebebi de, kamu sektörüne ya da özel sektöre ait yönetim modellerinin kopya edilmesiyle yetinilerek gönüllü kuruluşlara özgü yönetim modelleri geliştirilememesidir.

$\mathrm{Bu}$ bağlamda gönüllülerin çalışma isteklerinin, günümüz şartlarında pozitif değere dönüşebilmesi için gönüllü yönetimi büyük önem kazanmaktadır. Bu sebeple çalışmamızda STK'larda en kıymetli varlık olan insan servetini oluşturan gönüllülerin yönetimine ilişkin teorik bilgiler sunulduktan sonra, gönüllü yönetiminde çok önemli bir aşama olan performans değerlendirme konusu teorik ve uygulamalı olarak incelenmiştir.

Gerek gönüllü kuruluşun gerekse gönüllünün başarısını ayrı ayrı ve somut kriterlerle ölçmek gerekmektedir. Bunun için, mevcut çalışmalardan da yararlanılarak gönüllü kuruluşlara ve gönüllü yönetimine özgü bir performans değerlendirme modeli geliştirmek gerekmektedir.

\section{Gönüllülük Kavramı}

Gönüllülük, bir bireyin maddi karşılık beklemeden ya da başka bir çlkar beklentisi içinde olmadan, sosyal sorumluluk anlayışıyla, ailesi ya da yakın çevresi dışındaki bireylerin yaşam kalitesini artırmak ya da refah seviyesinin eşit bir biçimde dağılmasını ve yükseltilmesini sağlamak için, kendi isteğiyle, bir toplumsal girişime veya bir sivil toplum kuruluşu bünyesindeki etkinliklere kendi bilgi, beceri, deneyim, finansal kaynaklar ve zamanını kullanarak destek olması biçiminde tanımlanabilir (Güder, 2006: 4). Gönüllü ise, sivil toplum kuruluşlarının faaliyetlerinde yer alırken iş hayatındaki 
konumunu ve alışkanlıklarını bir kenara bırakarak, kuruluşun misyonunu gerçekleştirmek için en yüksek düzeyde performans sergilemeye çalışan sorumluluk sahibi ve fedakâr bireydir (Argüden ve Ilgaz, 2006: 87).

Gönüllülüğün birçok farklı tanımlaması mevcut olmasına rağmen gönüllülükle ilgili yapılan her çalışmada öne çıkan temel unsurlar, gönüllülüğün zorunlu olmaması; bedel karşılığı olmaması; kurumsal yapı içinde gerçekleşmesi ve kamu yararı amacıyla kamuya yönelmiş olmasıdır (Palabıyık, 2011: 90). Gönüllülüğün kişisel gelişime yaptığı katkıları değerlendirecek olursak bunlar, insanlar arasında bağı güçlendirme, sosyalleşme, değer görme, değer verme, hoşgörü, paylaşımcılık, diğerkâmlık, aidiyet ve güven gibi birçok olumlu duyguyu geliştirme şeklinde sıralanabilir. Bu yönüyle gönüllülük hem hizmet eden bireyler hem de hizmet talep eden bireyler açısından pozitif kazanç oluşturmaktadır.

\subsection{Bireysel ve Kurumsal Gönüllülüğü Doğuran Sebepler}

Gönüllülerin bir sivil toplum kuruluşuna üye olmalarının en büyük etkenleri arasında o kuruluşun faaliyetlerine ilgi duyması ve o alanda katkı yapma isteği gelmektedir. Gönüllüleri STK'lara sundukları hizmetlerin niteliği açısından bireysel ve kurumsal gönüllük şeklinde iki kategoride ele almak mümkündür.

Kurumsal olarak gönüllü hareketlerin içinde bulunmak genellikle özel sektörün kurumsal sosyal sorumlulukları kapsamında gerçekleşmektedir. Hem bireysel hem de kurumsal olarak gönüllüleri gönüllü olmaya iten sebepler mevcuttur. Bunları gözden geçirdiğimizde; bireysel gönüllüleri gönüllü olmaya iten sebepler arasında bireylerin yalnızlıklarını giderme isteği, örnek bir kişi olma isteği, yetki alma isteği, aitlik hissi, kariyer geliştirme isteği, sosyalleşme ihtiyacı, entelektüel düzeyini geliştirmek, hünerlerini paylaşma isteği, sahip olduğu parasını iyi amaçlara kullanma isteği, mirasını hayır işlerinde kullanacak STK'lara bırakmak, hayır işleri yapıyor gözükerek imajını iyileştirmeye çalışmak, inançsal etkenler, moda bir trend olduğu için, becerilerini geliştirme isteği ve bunun gibi bir çok sebepler sıralanabilir. Kurumsal gönüllüleri gönüllü olmaya iten sebepler ise, kurumun yöneticisinin gözüne girme, gönüllülükte başarılı olarak kariyer firsatı yaratma, kurumsal açıdan toplumda iyi şirket imajı yaratma, sosyal sorumluluk bilincinde olma, pazarda rakiplere karsı rekabet avantajı 
sağlama, vergiden muafiyet ve bunun gibi etkenler sıralanabilir (AFL Club Management Program, 2004: 8; Özmutaf, 2007: 153-154).

\subsection{Gönüllülük Keyfilik Değildir}

Gönüllülerin hizmet verdiği sivil toplum kuruluşuna karşı kuruluşun diğer paydaşlarına göre en az seviyede sorumlulukları vardır. Fakat bir sivil toplum kuruluşunun gönüllüsü olduktan ve bir görevle görevlendirildikten sonra gönüllünün o işi isteyerek gönülden yapması gerekir. Gönüllünün üzerine aldığı işleri yapmaması, geciktirmesi ya da önemsememesi gönüllüden beklenmeyecek davranışlardır. Sivil toplum kuruluşları her ne kadar amatör bir ruhla yönetiliyor olsa da profesyonelliği kaybetmemesi, sivil toplum kuruluşlarının misyonlarını gerçekleştirebilmeleri için oldukça önemlidir. Bu açıdan gönüllünün istediği işi kendisi seçtikten sonra bu işi profesyonel bir şekilde yerine getirmesi gerekmektedir (Özden, 2008: 58).

\subsection{Gönüllülüğün Sivil Toplum Kuruluşları Açısından Önemi}

Gönüllü kuruluşlarda insan kaynaklarının önemli bir çoğunluğunu oluşturan gönüllüler, kuruluşun gücünü belirleyen önemli göstergelerdendir. Geniş ve nitelikli gönüllü tabanı, gönüllü kuruluşun parasal imkânlarıyla belki de hiçbir zaman sahip olamayacağı insan kaynağını, maddi bir harcama yapmadan kullanabilmesi anlamına gelmektedir. Bunun yanında STK'ların kısıtlı bütçelerle gerçekleştirmek istedikleri hizmetler, sahip oldukları gönüllü tabanının katılım ve katkıları ile mümkün hale gelebilmektedir (Akatay, 2008: 125-125).

Gönüllüler, sivil toplum kuruluşlarının misyonlarının gerçekleştirilmesinden başlayarak STK'lara çok yönlü faydalar sağlamaktadırlar. Öncelikle STK'ların nitelikli gönüllü sayısı STK'ların başarılarının bir göstergesidir. Bunun yanında bütün gönüllülerin farklı bilgi ve becerilere sahip olmaları ve aynı zamanda yenilikçi ve girişimci olmaları kurum adına fayda sağlayacak bir durumdur. Böylelikle STK'lar bir olayı birçok farklı gözden görebilmekte ve özgün yeni bakış açıları edinebilmektedirler. Her yeni ve profesyonel katkı kurumun verimliliği adına somut kazanımlar sağlamaktadır. 
Gönüllüler, sivil toplum kuruluşlarının toplumdaki temsilcileri oldukları kadar aynı zamanda sivil toplum kuruluşları içerisinde toplumun temsilcileridirler. Toplumun gereksinimini bilen, toplumun temsilcisi olan gönüllüler STK'lara katkı sağlayarak kurumun faaliyetlerini geliştirebilir ve farklı projelerin üretilmesinde fikir ortaya koyarak kurumun etkinliğinin artmasında fayda sağlayabilirler.

Bütün bu açılardan gönüllü kaynağın etkili kullanımı, sivil toplum kuruluşlarının toplum tarafından tanınmasında ve benimsenmesinde önemli bir avantaj sunmaktadır. Gönüllüleri ve gönüllü faaliyetleri etkin olan sivil toplum kuruluşlarının hizmet kalitesinin ve sürdürülebilirliğinin, dolayısıyla rekabet gücünün bariz şekilde emsallerinden üstün olduğu açıkça gözlenebilmektedir.

\section{Gönüllü Yönetimi}

Ortak hedefler doğrultusunda; belirli bir kitleyi organize etmek, işbirliklerini arttırmak, elde edilen sonucun kaliteli düzeyde olmasını sağlamak gibi birçok sebepten dolayı kaçınılmaz bir süreç olarak karşımıza çıkan yönetim olgusu sadece kamu ve özel sektör kurum ve kuruluşları için değil, gönüllü kuruluşlar için de büyük önem arz etmektedir. Sürdürülebilirlik açısından tüm sektörler için zorunlu hale gelmiş olan yönetim sürecinin, sayıları ve etkileri gittikçe artan gönüllü kuruluşların kurumsal kimlik kazanması için çoğu faaliyetlerini 'gönüllü yönetimi' kurallarına göre yürütülmesi elzem olmuştur.

\subsection{Gönüllü Yönetiminin Kapsam ve Tanımı}

'Gönüllü yönetimi' literatürde oldukça yeni bir kavramdır. Geçmişe bakıldığında sivil toplum kuruluşlarının fazla sayıda gönüllüsü olmayan kuruluşlar olduğu ve gönüllüler daha çok gönül bağlılığı ile tamamen amatörce gönüllülük süreci içerisinde yer almaktaydı. Günümüze gelindiğinde sivil toplum kuruluşları, sayılarının artması ve neredeyse bir zorunluluk olarak kurumsallaşması ile birlikte formel bir yapıya bürünmüştür. Bu durum ise profesyonel anlamda insan kaynağı yönetimini yani gönüllü yönetimini gerekli kılmıştır. 
Gönüllü yönetimi, uygun işe gönüllü seçiminin yanı sıra gönüllülerin sürekli bilgilendirilmelerini, görev tanımının yapılarak ilgili sosyal konuda etkin ve sürdürülebilir çözümler geliştirmeyi, organizasyon ve gönüllü adına daha net bir süreç elde etmeyi, gönüllüler arasında daha eşit ve profesyonel hizmet dağılımını ve yaptıkları faaliyetlere yönelik motive edilmelerini içeren tatmin edici bir süreçtir.

Profesyonel bir gönüllü yönetiminde gönüllülerin görev tanımlarının yapılması çok önemlidir. Görev tanımlarının tam yapılmaması gönüllüler için motivasyon düşürücü nedenlerden birisi olup, bu durum gönüllülerde kafa karışıklığına yol açar ve böylelikle etkili bir hizmetin sergilenmesi önlenmiş olunur. Bunun yanında başarılı bir gönüllü yönetimi, gönüllülerin beyinlerine ve gönüllerine hitap edebilmeyi ve gönüllülük duygusunu sürekli dinamik tutabilmeyi gerektirmektedir (Citizens Information Board, 2008: 6; Sarıkaya, 2011: 65).

\subsection{Türkiye'de Gönüllü Yönetimi İhtiyacı}

Türkiye'de Temmuz 2015 itibari ile dernek ve vakıf olma üzere toplam 113 bin kadar sivil toplum kuruluşu faaliyet göstermekte, bu sayıya sendikalar, meslek odaları ve kooperatiflerin de eklenmesi durumunda toplam STK sayısı 150.000'i aşmaktadır. Türkiye nüfusuna oranla oldukça düşük sayılabilecek bu sayıya göre ülke genelinde ortalama her 800 kişiye bir STK düşmektedir. Üye sayısı da düşük düzeyde olup 150 bin STK'ya üye olan kadın sayısı yaklaşık 1 milyon 650 bin iken, erkek üye sayısı 7 milyon 250 bindir. Üyeler dışındaki gönüllülerin sayısı ise Türkiye'de \%7 oranında kalmaktadır (DDB, 2015). STK'ların kurumsallaşma düzeyi düşük kalmakta ve bunun en büyük sebebi olarak sorunlu yönetim yapısı görülmektedir.

Gönüllüler her geçen gün daha fazla sayıda kişiye hitap etmektedir. Gönüllülerin geniş kitlelere etki ediyor olması, yaptığı hizmetin bilincinde olan, kurumun misyonunu o kurumun örgütsel vatandaşı olarak sahiplenen ve profesyonel anlamda hizmet eden gönüllülerin varlığını zorunlu kılmaktadır. Yine bu noktada etkin bir gönüllü yönetimine olan ihtiyaç gözlemlenmektedir. Bu duruma birde gönüllülerin geçmişe oranla daha çok eğitimli, daha yüksek motivasyona sahip, daha fazla bilgi, beceri ve donanımı olan ve sorgulayan bireyler olması profesyonel gönüllü yönetimi ihtiyacını daha fazla arttırmaktadır (Flood vd., 2005: 80). 
Etkili bir gönüllü yönetimi ile gönüllüler, kurumun amaçlarını benimserler, hizmetleri verimli hale gelir, kurumun temsilcileri olduklarını bilerek hareket ederler, kurum için fikirler üretirler ve kurumun etkinlik gösterdiği alanlarda daha çok bilgi sahibi olurlar.

\subsection{Gönüllü Yönetiminin Temel Aşamaları}

Gönüllüler sivil toplum kuruluşları için oldukça önemlidir ve birçok sivil toplum kuruluşunun kısıtlı bütçelerle ve güçlükle yürüttükleri projeler, gönüllülerin desteğiyle mümkün hâle gelmektedir. Gönüllülerin kurumla bütünleşmesini sağlayarak ve potansiyellerini ortaya çıkararak kaliteli bir sonuç elde etmek etkili bir gönüllü yönetimiyle gerçekleşecektir. Gönüllü yönetimi süreci sekiz temel aşamadan oluşmaktadır:

1. Gönüllülerin görev çerçevelerinin belirlenmesi ve tanımlanması

2. Gönüllülere ulaşma

3. Gönüllülerin kuruma oryantasyonu

4. Görevlendirme ve seçim

5. Kurum içi eğitim

6. Gönüllülerin motivasyonu

7. Performans değerlendirme

8. Ödüllendirme

\subsection{Gönüllü Yöneticisi}

Gönüllü yönetimi sürecinin aşamalarını etkin şekilde gerçekleştirilmesi için STK'ların öncelikle görevini profesyonel bir şekilde gerçekleştiren gönüllü yöneticisine ihtiyaç bulunmaktadır. Gönüllü yöneticileri, gönüllüleri, yani hiçbir karşılık beklemeksizin hizmet eden grubu yönetmektedir. Bu durumun olumlu yönleri olduğu gibi olumsuz yönleri de mevcuttur. Olumlu yönlerinden birisi, bireylerin tamamen hür iradelerine bağlı olarak hizmet sunmasıdır. Yani yönetilen grup istekli ve heveslidir. $\mathrm{Bu}$ açıdan gönüllünün kendisiyle ilgilenen bir yöneticinin varlığından haberdar olması ve onu doğru bir şekilde yönlendireceğini bilmesi motivasyonunu ve dolayısıyla hizmet kalitesini arttıracaktır. 
Olumsuz yönüne baktığımızda, bireylerin gönül bağlılığı dışında hiçbir bağlarının bulunmaması gönüllü yönetimini zorlaştırmaktadır. Kamu sektöründe olduğu gibi özel sektörde formel bir yapı mevcuttur, kurallar bellidir ve bireyler belirli bir ücret karşılığında hizmet etmektedirler. Bu açıdan da yönetilmeleri daha kolaydır. Ancak gönüllü kuruluşlarda gönüllülerin maddi açıdan bir beklentileri yoktur ve gönüllüler olumsuz bir durumla karşılaştığında ya da birçok sebepten dolayı hiçbir neden göstermeksizin gönüllülüğü bırakabilir. Böyle bireylerin yönetilmesi elbette daha zordur.

Bunun yanında etkili bir gönüllü yönetimi desteğiyle kaliteli hizmet sunan gönüllüler, toplum içinde bir grubu temsil etmektedirler, onların haklarını savunmakta ve onların gelişmesine katkıda bulunmaktadırlar. Ayrıca dezavantajlı gruplara hizmet eden STK'larda ise gönüllüler, sosyal sorunları olan bireylere yardım etmekte ve onlara toplum içerisinde yalnız olmadıklarını göstermektedirler. Yapılan bütün bu hizmetler karşılığında gönüllülerin elde edeceği en büyük çıktı manevi doyumdur. Bu doyum, hizmet ne kadar kaliteli yapılıyorsa o denli fazla hissedilecektir. Yani kaliteli bir gönüllü yönetimi ile gönüllülerin hizmetlerinin daha verimli hale getirilmesi hem gönüllü açısından, hem hizmet sunulan grup açısından, hem de kurumun amaçlarını gerçekleştirmesi açısından oldukça önemlidir.

Sivil toplum kuruluşlarının en önemli unsurları olan gönüllülerin profesyonel bir şekilde yönetilmesi açısından öncelikle yukarıda belirtilmiş olan bütün faktörler dikkate alınarak uygun bir planlama yapılmalı ve gönüllü yönetim süreci oluşturulmalıdır. Biz bu çalışmamızda sekiz aşamalı sürecin performans değerlendirme aşamasına yoğunlaşacağı.

\section{Performans Değerlendirme}

Genel olarak bir sivil toplum kuruluşu açısından bakıldığında STK'ların esas misyonlarından sapmamaları için, stratejik hedeflerine ne ölçüde ulaştıklarını ölçmeleri gerekmektedir. Bu da performanslarını değerlendirme aşaması ile olur. Ancak, STK'ların performans ölçüm ve yönetim sistemi, özel sektörde olduğu gibi sadece finansal performansa bağlı değildir. Bunun ötesinde finansal olmayan alanlardaki performanslar 
da dikkate alınmalıdır. Bütün bu süreçleri gerçekleştirmek için STK'ların kendine has performans ölçüm sistemine ihtiyaçları vardır. Genel olarak STK'ların performansı ölçülürken kurumun verimliliği, üretkenliği ve etkililiği ölçülerek performansı değerlendirilebilir. Özetle STK'lar, verimli çalışabilmeleri ve varlıklarını sürdürebilmeleri için performans değerlendirmesi ve yönetimi yapmak zorundadırlar. Çünkü performans ölçümü ile organizasyonun genel olarak ne kadar başarılı olduğu, toplumun isteklerini karşılayıp karşılayamadığı ve planlanan gelişmelerin gerçekleşip gerçekleşmediği belirlenmektedir (Coşkun, 2006: 104-106).

\subsection{Gönüllü Kuruluşlarda Performans Değerlendirme İhtiyacı}

Performans değerlendirme sürecinin içerisinde gönüllülerin de performansının değerlendirilmesi aşaması mevcuttur. Gönüllünün değerlendirilmesi, gönüllülerin gerçekleştirdiği faaliyetlerin, bu faaliyetleri gerçekleştirirken gösterdiği performansın ve elde edilen çıktının değerlendirilmesidir. $\mathrm{Bu}$ ölçümler daha önce de belirtildiği gibi STK'ların kendi bünyesinde oluşturduğu performans ölçüm sistemi ile yapılabilecektir.

Sivil toplum kuruluşlarının değerlendirilmesi zor bir iştir. Çünkü STK'larda maddi beklentilerden çok manevi beklentiler ön plandadır. Bunun yanında bir gönüllü açısından düşünüldüğünde, zaten gönüllü olarak katıldığı bir kurumun gerçekleştirdiği bir faaliyet sonunda performansının değerlendirileceğini beklemez. Ancak gönüllü açısından performans değerlendirmenin olumlu etkileri de söz konusudur. Gönüllünün değerlendirilmesi, yaptığı işten geribildirim alması bakımından ve kurumun profesyonel olarak yapılan hizmetleri takip ediyor olması bakımından gönüllünün motive olmasını sağlar. Bunun yanında kurum açısından değerlendirildiğinde ise gönüllüyü takip edebilme imkânı sağlar. Böylelikle gönüllünün görevine uygunluğu, hangi gönüllünün nasıl görevlendirileceği gibi önemli kararların sağlıklı bir şekilde verilmesi açısından fayda oluşturur. Aynı zamanda gönüllünün eksik olduğu alanlarda eğitilmesi için de bir firsat sağlar (Yaman, 2005: 57).

Genel olarak bakıldığında bir birey gönüllü hizmetlere katılıyor da olsa kurum içerisinde bulunduğu sürece değerlendirme aşaması süreklilik arz edecektir. Gönüllü belirli aralıklarla belirli amaçlarla değerlendirilecektir. Kuruma kabul edilme sürecinde beceri, tecrübe ve beklenen özellikleri açısından değerlendirilirken, sonrasında gösterdiği performansla değerlendirilir. Dolayısıyla gönüllünün, kișisel gelişimi, 
gönüllülerle etkileşimi, görevini benimsemesi ve kurumu içselleştirmesi gibi özellikleri performansını belirleyecek unsurlar arasında yer alır (Serbest, 2003: 48).

Performans değerlendirme sonucunda olumlu çıktıların elde edilmesi ile birlikte gönüllülerin ödüllendirilmesi çok önemlidir. Gönüllü faaliyetlerde, gönüllülerin motivasyonu yapılan işin pozitif değerini arttırır. $\mathrm{Bu}$ bakımdan gönüllüler ödüllendirilerek motive edilmelidir.

\subsection{Gönüllülerin Performans Değerlendirmesi}

Sivil toplum kuruluşlarının gönüllülerine ilişkin bilgileri toplaması ve gerekli olduğunda bunlardan istatistikî bilgi alabilmesi, kurumun ileride yapacağı plânlama faaliyetlerine de zemin hazırlayacaktır. Gönüllü yönetiminin ilk safhası olan plânlama, gönüllü bilgilerinin mevcudiyeti ile daha gerçekçi bir şekilde yapılabilecektir. Bununla ilgili olarak yurt dışında yapılmış bazı bilgisayar yazılımları mevcuttur. Bu yazılımlar sayesinde gönüllülerin neler yaptıkları, nerede başarılı oldukları, bir daha kendilerine ne gibi görevler verilebileceği, ne gibi görevlerin verilmemesi gerektiği ve benzeri bilgiler kolaylıkla elde edilebilmektedir. Belki çok gelişmiş yazılım programlarıyla değilse de en azından Excel, Access vb. hazır programlar ile her sivil toplum kuruluşu bir gönüllü veri tabanı oluşturmalıdır.

İstihdam sağlayan temel alanlar olarak kamu kesimi ve özel sektörde personele verilen görevin ne düzeyde başarıldığını gösteren davranış ölçme cetvelleri geliştirilmiştir. Performans değerlendirme formu adını taşıyan, kurumların ve iş yerlerinin özelliklerine göre belirlenmiş, kurumun ve çalışanların başarısını ve verimliliğini ölçen çok farklı değerlendirme cetvelleri kullanılmaktadır. Literatüre geçmiş grafik değerlendirme, puanlama, kontrol listesi, derecelendirme, zorunlu seçim, puan tahsis, davranışsal değerlendirme, ikili karşılaştırma ve 360 derece performans değerlendirme gibi birçok performans değerlendirme yöntemleri bulunmaktadır.

Kamu sektöründe ve özel sektörde başarılı olsa da yönetici görüşleri odaklı klasik performans değerleme yöntemlerinin gönüllü kuruluşlarda sağlıklı bir sonuç vermesi mümkün görünmemektedir. Gönüllü hizmeti sunan ve bu hizmetten yararlanan kişilerin tatmin derecesini esas alan performans değerlendirme modeli STK'lar için daha elverişli olacaktır. 
Gönüllü kuruluşlar, kâr beklentisi olmayan gönüllü personeli yetenek ve ilgileri doğrultusunda daha verimli olacağı birimlerde çalıştırılmalıdır. Gönüllülerle doğru zamanda doğru geribildirimler verilmeli, hizmetleri değerlendirmeye tabi tutulmall, yaptıkları işlere, gösterdikleri performanslara dair gözlemler ve ölçümler yapılmalı, kurumda önceden belirlenmiş kriterlere göre yorumlanarak ilgililere bildirilmelidir.

Değerlendirme gönüllüler açısından motive edici olabilir. Gönüllülerin kendilerinden beklenen hizmeti ne derece başardıklarını öğrenme hakları vardır. Olumlu değerlendirmeler gönüllünün onaylanması için bir temel oluştururlar. Olumsuz değerlendirmeler ise gönüllünün kendisini geliştirmesi gereken alanları belirlemede yardımcı olurlar.

Samimi ilişkilerin daha yoğun olduğu gönüllü faaliyetlerin objektif değerlendirmeye tabi tutulması kolay değildir. Ne var ki, sayıları yanında nitelikleri de artan ve belli hizmet dallarında uzmanlaşmaya başlayan gönüllü kuruluşlarda belirli bir program uygulanması ve somut çıktılar elde edilmesi sebebiyle gönüllü çalışmaların değerlendirilmesi de zorunlu hale gelmiştir. Kaldı ki, proje bazında ve fon desteği alarak faaliyet yürütme alışkanlığının STK'lar arasında hızla yayılması performans değerlendirme kültürünün gelişmesini kaçınılmaz kılmaktadır.

\subsection{Gönüllü Kuruluşların Performans Değerlendirmesi}

Performans değerlendirme gönüllünün yanı sıra kuruluşun kendini geliştirmesine yardımcı olur. Değerlendirme sonucunda risk olan birimlerde önceden önlem alınır ki sonradan probleme dönüşmesin. Yapılan her değerlendirmenin belgeleri saklanmalıdır.

Gönüllü faaliyetleri yanında gönüllü kuruluşun hizmet kalitesini arttırması için vizyondaki hedeflerine ulaşıp ulaşmadığını kontrol ederek kuruluşunun etkinliğini ölçmesi gerekir. Özel sektörde kuruluşları elde ettikleri gelirlerle değerlendirilirken sivil toplum kuruluşları elde edilen gelirden ziyade doğrudan insana yönelik hizmetleriyle değerlendirilmelidir. Genel olarak bir sivil toplum kuruluşu açısından bakıldığında STK'ların esas misyonlarından sapmamaları için stratejik hedeflerine ne ölçüde ulaştıklarını ölçmeleri gerekmektedir. Bu da performanslarını değerlendirilme aşaması ile olur. Ancak STK'ların performans ölçüm ve yönetim sistemi, özel kuruluşlarda olduğu 
gibi sadece finansal performansa bağlı değildir. Bunun ötesinde finansla ilgisi olmayan alanlardaki performanslar da dikkate alınmalıdır. Bütün bu süreçleri gerçekleştirmek için STK'ların performans ölçüm sistemine ihtiyaçları vardır. Genel olarak STK'ların performansı ölçülürken kurumun verimliliği, üretkenliği ve etkililiği ölçülerek performansı değerlendirilebilir.

Kurum ve kuruluşların etkinliklerin devamlılığı ve hizmetin sürdürülebilirliği için yapmış oldukları çalışmaların sonuçlarını çıkarmaları gerekmektedir. Hizmet kuruluşlarında kendi arzusuyla ücretsiz çalışan gönüllülerinin, yaptıkları işlerin derecelendirilmesi, yetenekli oluşu, kuruma olumlu yararlar sağlamsının sonucunda çalışmalarının değerlendirilmesi ve olumlu geri bildirimlerin alınması gönüllü çalışanın devamlılığı sağlanmış olur.

\subsection{Sağlıklı Bir Değerlendirmenin Esasları}

İstanbul'da bazı belediyelerin ve ülke çapında faaliyet gösteren bazı STK'ların 'gönüllü programı geliştirme' çalışmaları, gönüllülerin performans değerlendirmesine ilişkin yeni bir model önerisinde yararlanılması gereken çalışmalardır. Bu bilgilere göre, değerlendirme boyunca sakin bir ortam sağlanması, gönüllülerin güçlü yönleri vurgulanarak ardından geliştirilmesi gereken yönlerine dikkat çekilmesi ve somut örneklerle desteklenmesi, gönüllülerin yorumlarının dinlenerek yönetim tarafından değerlendirilmesi gerekir.

1. Gönüllü çalışanlar performans ölçümlerinin yapılmasını, çalışmalarının ne düzeyde olduğunu, beklenen performansı sergileyip sergilemediklerini öğrenmek isterler. Zira hangi alanlarda başarılı olduklarını, üstlendikleri görevde başarılı olup olmadıklarını, aynı zamanda hangi anlarda zayıf kaldıklarını öğrenip, eksik yönlerini tamamlama firsatı elde etmek isterler.

2. Performans ölçümü yapılırken doğru ölçütler kullanılmalıdır. Ortamın dikkat dağıtmayan ve davranış değişikliğine neden olacak etkenlerden uzak olması gerekmektedir. Performans ölçümü yapılırken doğal gözleme de başvurulmalıdır ki gönüllünün gerçek davranışları ölçülebilsin. 
3. Değerlendirme sonuçları gönüllünün motivasyonunu kırmadan açıklanmalıdır. Değerlendirme ölçütü kişilik özelliklerini değil çalışma şeklini ölçmelidir. Gönüllü, değerlendirme sonucunu reddetme hakkına sahiptir.

4. Değerlendirmeler iki türlü yapılabilir. Belirli aralıkla performans değerlendirmesi şeklinde toplantı haline dönüştürülebilir. Ya da gönüllüler belli aralıkla gözlemlenip yaptıkları işleri hakkında ne düşündükleri samimi ortamlarda, mesela birlikte çay kahve içerken sorulabilir.

5. Gelecekte soruna dönüşebilecek riskli alanları belirleyip önlem almak zorlukları azaltmak adına iyi bir yöntem olabilir.

6. Değerlendirmeler resmi olarak yapılmasa bile kaydı tutulmalıdır. Ölçüm esnasında gönüllünün bütün davranışları kayıt altına alınmalıdır. Gönüllünün sergilediği olumlu ve olumsuz davranışları göz önünde tutulmalıdır. Özellikle gönüllünün problem yaşadığı alanlarda ya da hizmet esnasında gösterdiği problem davranışları gelişmeyi takip etmek için gerekli olacaktır. Bütün değerlendirmeler gizli tutulmalıdır.

\subsubsection{Değerlendirme esnasında özen gösterilmesi gereken ilkeler}

Kadıköy Belediyesi'nin resmi internet sitesinden paylaştığı gönüllü değerlendirme kriterleri sıralanırken, değerlendirme esnasında özen gösterilmesi gereken şu maddeler sayılmıştır:

1. Yorumların adil olduğundan emin olunmalıdır.

2. Kişiye değil, işe odaklanılmalıdır.

3. Disiplinle ilgili prosedürler için organizasyonun kuralları takip edilmelidir. Bu kurallar oryantasyon aşamasında gönüllüye anlatılmış olmalıdır.

\subsubsection{Değerlendirme sonrasında atılması gereken adımlar}

Adı geçen belediyenin sitesinde gönüllü değerlendirme süreci sonrasında ise şu adımların atılması gerektiği vurgulanmıștır:

1. Ek eğitim ya da süper vizyon eğitimi 
2. Yeni bir görev verme

3. Görevden uzaklaştırma

4. Kişiyi organizasyondan uzaklaştırma.

5. Gönüllüler değerlendirme hakkında itiraz hakkına sahip olmalıdır. Böyle bir haklarının bulunduğu gönüllülere oryantasyon aşamasında bildirilmelidir.

\subsection{3. Çift Yönlü Değerlendirme}

Çift yönlü değerlendirme programı, hem gönüllüyü hem de programı değerlendirmede kolaylık sağlar. Düzenli değerlendirmeler organizasyonun ve gönüllülerin ihtiyaçlarını karşılamaya yardım eder. Program değerlendirmeleri gönüllü memnuniyetini artırmayı, programı geliștirmeyi, verimliliği arttırmayı ve maliyeti azaltmayı, problemleri ve çözümlerini tanımlayabilmeyi neyin işleyip neyin işlemediğini belirlemeyi sağlar.

Gönüllünün değerlendirilmesi programın da değerlendirildiği anlamına gelmez. Program değerlendirmeleri aracılığı ile yürütülen projenin de değerlendirilmesi sağlanabilir. İki yönlü ölçüm yapmak hem programı hem de gönüllüyü değerlendirmek için rahatlık sağlar. Sürekli yapılan ölçümler gönüllülerin isteklerini belirtemeye ve yerine getirmeyi sağlar.

Gönüllünün değerlendirilmesi gönüllünün yaptıkları işlere gösterdikleri performanslara ilişkin ölçümlerin kurumda önceden belirlenmiş birtakım kriterlere göre yorumlanmasıdır. Değerlendirme işi doğası gereği zor bir iştir. Çünkü bir gönüllü, bir sivil toplum kuruluşuna katılırken genellikle herhangi bir faaliyet sonunda değerlendirilmeyi amaçlamaz. Buna rağmen gönüllüler, değerlendirmelerin yararlı yönleri sebebiyle göz ardı edilemeyeceğini de anlayabilirler.

Gönüllülerin değerlendirilmesinin bir başka faydası, verilen hizmetlere objektiflik katabilmesidir. Bunun dışında değerlendirme, kurum içinde yükselme, rotasyon ve diğer yatay-dikey görevlendirmelerde temel teşkil edecektir. Kurumda değerlendirme için kullanılacak performans ya da diğer tür standartların yazılı olması beklenir. Ancak aranması gereken tek şart, bunların değerlendirilecek kişi tarafından bilinmesidir. 
Kurum içinde yapılacak bu tür değerlendirilmelerin muhafazası ve gönüllülere ait özel bir takım bilgilerin özenle saklanması gerekmektedir. Kurum içinde değerlendirme işlemin kimin tarafından yapılacağı ise doğal olarak kurumdan kuruma değişiklik arz edebilecektir. Çalışan sayısı ya da faaliyet ağı nispeten büyük olan kurumlarda bu iş, ayrı bir ekip tarafından yürütülebilirken, daha küçük ölçekli STK'larda müdür veya bu iş için görevlendirilen bir yönetici ya da gönüllü yöneticisi tarafından yapılabilir. (EDAM, 2003).

Performans değerlendirme sonucunda gönüllü çalışanların ödüllendirilmesi gönüllülerin güdülenmesine ve daha istekli çalışmalarına neden olur. $\mathrm{Bu}$ da hem kurumun ilerlemesine olumlu katkılar yapar hem de gönüllünün devamlılığı sağlanmış olur. İki yönlü değerlendirme gönüllünün kurum hakkında güvenini arttırmasına ve daha istekli çalışmasına hizmet eder. Aynı zamanda gönüllünün kendisini daha iyi tanımasına ve yeteneklerini ortaya çıkarmasına yardımcı olur. Böylece gönüllünün daha yararlı olacağı birimde çalışmasına da yol açılmış olur.

\section{Gönüllü Kuruluşlarda Performans Değerlendirme Sistemi}

Kamu ve özel sektör çalışanlarına uygulanan çeşitli performans değerlendirme sistem ve tekniklerinden de yararlanarak gönüllü kuruluşların yapısal özelliklerine uygun şekilde gönüllü değerlendirme modelleri geliştirilmesine şiddetle ihtiyaç duyulmaktadır. Zira, gerek nitelik gerekse nicelik açısından dünyada olduğu gibi ülkemizde de artarak devam eden gönüllü kuruluşlarda nitelikli gönüllü katılımının belirgin bir yükselişe geçmesi gönüllü yönetimi ilkelerine riayet etmekle ve gönüllü performansını STK'lara özgü bir modelle değerlendirmeye de bağlıdır.

\subsection{Gönüllü Performans Değerlendirme Formu}

Her hangi bir performans değerlendirme formunda aşağıdaki örnekte yer verilen bilgilere benzer sorular yöneltilerek oluşturulacak cetveller gönüllülerin çalışma potansiyellerini ölçme aracı olarak kullanılabilir: 
Şekil 1: Gönüllü Performans Değerlendirme Formu

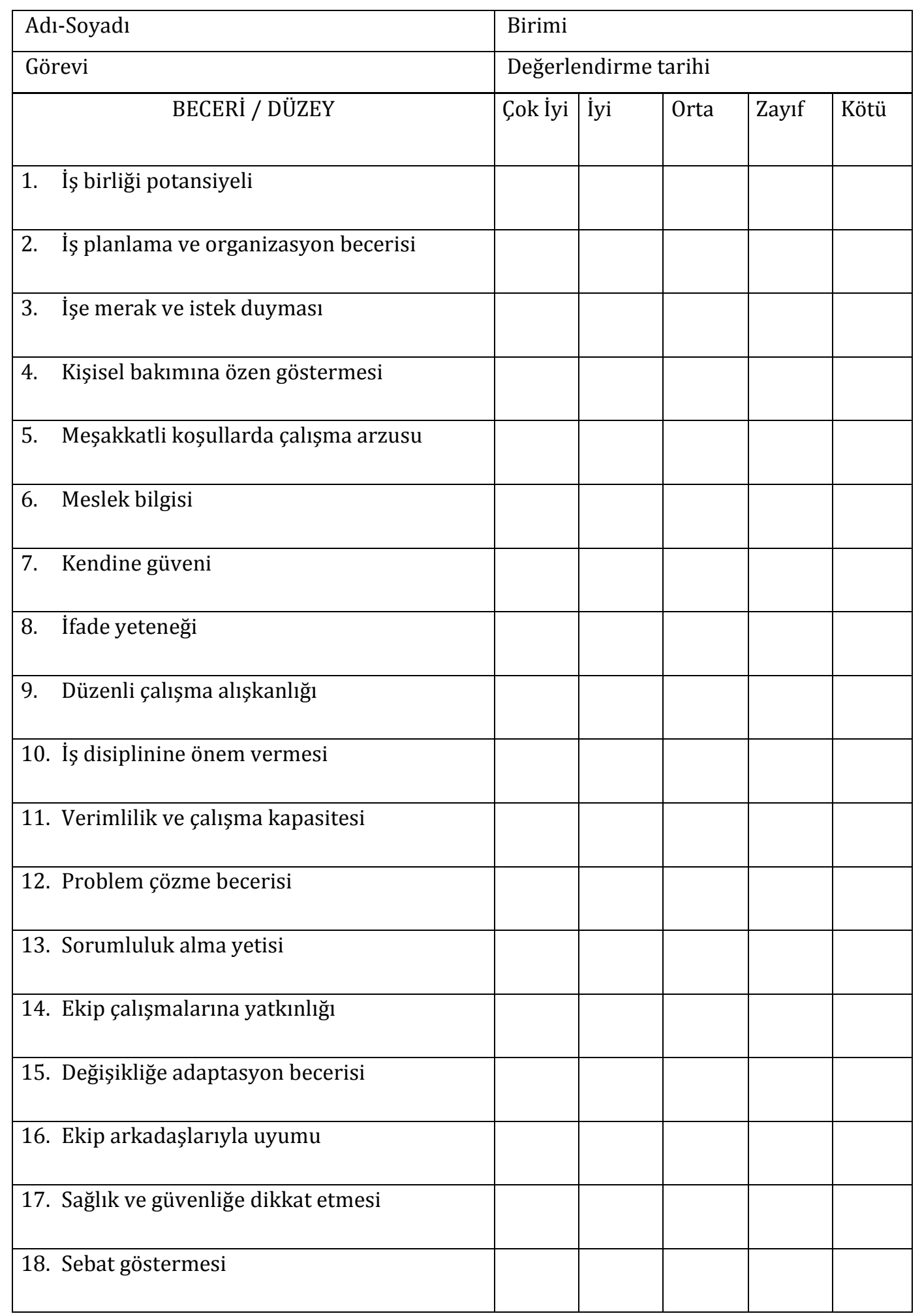




\begin{tabular}{|l|l|l|l|l|l|} 
19. Kişi haklarına saygılı olması & & & & & \\
\hline 20. İnsan ilişkileri & & & & & \\
\hline 21. Ekip arkadaşlarıyla kaynaşması & & & & & \\
\hline
\end{tabular}

Kurumun, projenin ya da katılımcı gönüllü kitlenin yapısına göre bazı ölçüm maddelerinden sarf-ı nazar edilebileceği gibi yeni maddelerin ilave edilmesi de mümkündür. Nitelikli gönüllü gruplarında bazı bilgiler mahrem alan içinde görülebilmekte ve yöneltilen soru karşısında rahatsız olabilmekte, hatta ürkerek projeye katkı yapmaktan vaz geçebilmektedir. Bu husus göz önünde bulundurularak her çalışma için ayrı form düzenlenmeli ve gönüllü performans değerlendirme formunda gönüllü grubunun hassasiyetleri dikkate alınarak gerekli ilave ve çıkarmalar yapılmalıdır.

\subsection{Gönüllü Öz Değerlendirme Formu}

Gönüllülerin performansını sadece dış gözlemcilere dayanarak değerlendirmek yeterli olmayacaktır. Gönüllünün iç gözlem tekniğiyle kendisini değerlendirmesi daha dengeli, yapıcı ve gönüllüyü kurumda kalıcı kılan bir netice doğuracaktır. Bunun için gönüllülerin kendi kendilerini değerlendirmelerine hizmet edecek formlar geliştirilebilir.

Gönüllüler için öz değerlendirme formları düzenlenirken aşağıdaki örnekte sıralanan sorulara yer verilerek gönüllünün bu soruları cevaplaması istenebilir. Gönüllünün özeleştirisini de barındıran bu tür bir değerlendirme kuruluş için olduğu gibi gönüllü için de daha yapıcı bir sonuç doğurabilecektir.

Şekil 2: Gönüllü Özdeğerlendirme Formu

\begin{tabular}{|l|l|}
\hline Adı-Soyadı & Birimi \\
\hline Görevi & Değerlendirme tarihi \\
\hline 1. Uygulanan faaliyette ne öğrendim? & \\
\hline 2. Hangi temada zorlandım? & \\
\hline 3. Hangisini iyi yaptım? & \\
\hline 4. Baskın yönlerim neler? & \\
\hline
\end{tabular}




\begin{tabular}{|l|l|}
\hline $5 . \quad$ Sonraki çalışmalarda nelere dikkat edeceğim? & \\
\hline 6. $\quad$ Eksik yönlerim var mı? & \\
\hline 7. $\quad$ Hangi alanda eksik yönlerim var? & \\
\hline 8. Hangi alanlarda zorlandım? & \\
\hline 9. Kendimi nasıl geliştirebilirim? & \\
\hline 10. Şu hususu da belirtmekte yarar görüyorum: & \\
\hline
\end{tabular}

Gönüllü öz değerlendirme formunda projeye ya da gönüllü grubunun yapısına göre değişiklikler yapılabilir. Gönüllülere yönelik soru cetvellerinde öngörülemeyen sorular için kendilerine inisiyatif tanıyan bir yer ayırmakta yarar bulunmaktadır.

\subsection{Derece Performans Değerlendirme Modeli}

360 derece performans değerlendirme yöntemi, çalışanın performansının; çalışanın iş arkadaşlarından, yöneticilerinden, üstlerinden, kendisine doğrudan rapor verenlerden (astlar), iç ve dış müşterilerinden, parçası olduğu proje takımlarının diğer üyelerinden ve de kendisinden derlenen spesifik iş performansı bilgilerinin ışı̆̆ında değerlendirilmesi sürecidir (Vinson, 1996).

Geleneksel performans yaklaşımında çalışana sadece üstü tarafın- dan geribildirim verilmesine karşılık, 360 derece performans değerlendir- me yöntemi, çalışanın performansını gözlemleyen daha geniş bir grubun çalışana geribildirim vermesine olanak sağlamaktadır (Yüce, 2003).

Bir taraftan kuruluşun bütün fonksiyonlarının ahenkli bir şekilde çalışmasının teminatı, öbür taraftan hem kuruluşa hem de çalışanlara geri bildirim vermesi açısından yönetsel yapının en önemli dayanağı olarak betimleyebileceğimiz 360 derece performans değerlendirme yöntemi, kurum hedefleriyle ilişkilendirilir, çalışanlara iyi anlatılır ve eğitimlerle pekiştirilip izlenirse, iyi sonuçlar verecektir. Ayrıca, değerlendirilenin elde edilen sonuçlara sahip çıkması, performans hedefi belirlemesi ve sonuçlardan sorumlu tutulması, başarı düzeyini olumlu yönde etkileyecektir (Bayram, 2005:63). 
Çalışanların belirli ölçütlerle, başarı durumları göz önünde bulundurularak yapılan bir değerlendirme olan sıralama ve derecelendirme gibi klasik yöntemlerin yanında kritik olay yöntemi, amaçlara göre değerlendirme yöntemi, davranışsal beklenti yöntemi, ölçekler aracılığıyla değerlendirme yöntemi, grafik değerlendirme yöntemi, puanlandırma cetvelleri, özdeğerlendirme, kompozisyon yöntemi gibi daha modern performans değerlendirme yöntemleri arasında, 1990’lı yıllardan itibaren Amerika ve Avrupa'da hızla yaygınlık kazanan 360 derece değerlendirme yöntemini üçüncü sektörde çalışan ve gönüllülerin performansını değerlendirmek için de kullanmak mümkün ve gereklidir.

Performans değerlendirme gönüllü ve çalışanların iş gücünü arttırmak ve kendilerini değerlendirmeleri, gönüllü kuruluşa sağladıkları fayda ya da zararı öğrenmeleri açısından önemlidir. Böylece çalışanın ya da gönüllünün kendini tanımasına yardımcı olur. $\mathrm{Bu}$ da gönüllüye ya da çalışana hangi alanlarda ve düzeyde verimli olabileceğinin cevabını öğrenmesine yardımcı olur. Yapılan değerlendirmeler personelin ya da gönüllünün alacağı görevde sorun yaşamamasına, işini ya da hizmetini severek yapmasına yardımcı olur. İnsan kaynakları biriminin gözlem ve ölçümü sunucunda görev verilmeden önce kişi hakkında daha kolay karar verilmesini sağlar.

\subsubsection{Derece Değerlendirme Yönteminin Yararları}

1. Çoklu değerlendiriciler modele dahil olduğu için daha objektif bir sonuç elde edilir.

2. Gönüllü, çevresinde nasıl bir imaja sahip olduğu ve sunduğu gönüllü hizmetin nasıl algılandığına ilişkin bilgi edinir.

3. Gönüllü, değerlerine ve yeteneklerine göre görevlendirilir.

4. Yapılan işin sonucunda değerlendirmeyle etkili geri bildirim alınır.

5. Yöneticiler, çalışan ve gönüllülerin yetenekleri, işi kavrama becerileri, bilgi düzeyleri ve kendini geliştirme iradeleri hakkında fikir sahibi olurlar. 


\subsubsection{Derece Gönüllü Performans Değerlendirme Modeli}

Mükemmel olduğunu iddia etmek mümkün değilse de 360 Derece Performans Değerlendirme Modeli gönüllü kuruluşların ve gönüllülerin performansının ölçülmesinde bir model olarak kullanılabilecek bir modeldir. Modelin ölçümü yapan ve hakkında ölçüm yapılan kişiye ilişkin verileri gönüllüye uyarlanarak şu şekilde düzenlenebilir:

Şekil 3: 360 Derece Performans Değerlendirme Formu-Giriş

\begin{tabular}{|c|c|c|}
\hline ÖLÇÜM YAPAN KIŞ̦i & \multicolumn{2}{|c|}{ Ölçümü yapılan kişi } \\
\hline $\begin{array}{ll}\text { Yönetim } & \text { Kurulu } \\
\text { üyesi } & \end{array}$ & Adı Soyadı & Yöneticisi \\
\hline Müdür & & $\begin{array}{l}\text { Gönüllü } \\
\text { personeli }\end{array}$ \\
\hline Sekreter & Görevi & $\begin{array}{l}\text { Personel } \\
\text { arkadaşı }\end{array}$ \\
\hline Çalışan & & Kişinin kendisi \\
\hline Gönüllü & & Hizmet alan kişi \\
\hline \multirow[t]{2}{*}{ Hizmet alan } & & \\
\hline & & Diğer .... \\
\hline Hizmetli & & \\
\hline
\end{tabular}

Ölçüm yapan kişi sütununa, gönüllü kuruluşun faaliyet alanına ve kadro büyüklüğüne göre ilaveler ya da çlkarmalar yapılabilir. Aynı şekilde hakkında ölçüm yapılan kişi sütununa gönüllünün çalıștığı birime ya da projeye göre ilaveler ya da çıkarmalar yapılabilir. 
Performansı ölçülecek gönüllüye ilişkin görüş belirten ilgili kişilerin kanaatleri 1 ila 6 arasındaki sayılarla kesinlik derecelerine ayrılarak şu şekilde bir şablon geliştirilmiştir:

Şekil 4: 360 Derece Performans Değerlendirme Formu- Varsayılan Belirtme Çizelgesi

\begin{tabular}{|c|c|c|c|c|c|}
\hline \multicolumn{6}{|c|}{ VARSAYILAN BELİRTME ÇİZELGESİ } \\
\hline $\begin{array}{l}\text { Kesinlikle } \\
\text { Katılmıyorum }\end{array}$ & Katılmiyorum & $\begin{array}{l}\text { Kismen } \\
\text { Katılmiyorum }\end{array}$ & $\begin{array}{l}\text { Kesinlikle } \\
\text { Katıllyorum }\end{array}$ & Katıliyorum & $\begin{array}{l}\text { Kısmen } \\
\text { Katılıyorum }\end{array}$ \\
\hline 1 & 2 & 3 & 4 & 5 & 6 \\
\hline
\end{tabular}

Performansın dengeli bir şekilde ölçülmesi için 6'lı ölçek belirlenmesi istatistik biliminin önerileriyle uyum sağlamamaktadır. Örnek olarak, kanaat ölçmede en sosyal bilimlerin en çok başvurduğu teknik olan likert ölçeğini esas alacak olursak, çift yerine tek rakamlı bir ölçek oluşturulması gerekecektir. Zira çift rakamlı ölçeklerde dengeli ölçüm sağlanamamaktadır. Ölçmek istediğimiz kanaati hassasiyet derecesine göre 3'lü, 5’li ya da 7'li ölçekler kullanarak ölçebiliriz. Ayrıca, 'kısmen katılmıyorum' şıkkını olumsuz formda değil, aynı anlama geldiği için 'kısmen katılıyorum' şeklinde ifade etmek daha uygun olacaktır. Bu ölçekte 6 numara ile kodlanan bu seçenek 3 numara ile kodlanan 'kısmen katılmıyorum' seçeneğiyle aynı anlama geldiği için onun yerine konabilir ve esasen bu ölçek 5'li likert ölçeği olarak kabul edilebilir. Ayrıca, likert ölçeğinde zıt iki uç arasında sıralı ve dengeli bir dağılım gerektiği halde yukarıda alıntılanan belirtme çizelgesinde bu kurala riayet edilmediği görülmektedir. Aynı şekilde gönüllünün meziyetlerini ölçen bir formda ilk seçenek olarak en kötünün sunulması mantıki olmadığından sıralamayı en olumlu kanaat için atanan rakamla başlatmak daha uygun olacaktır. Zira, gönüllüler zaten ölçülen becerilere ortanın üstünde ve iyi düzeyde sahip oldukları için gönüllü bir aktiviteye isteyerek ve severek katkı yapmaktadır.

Bu durumda bizim uygulanmasını önerdiğimiz ölçek şu şekilde olmaktadır:
1) Kesinlikle Katılmıyorum, 2) Katılmıyorum,
3) Kısmen Katılıyorum, 4) Katılıyorum
5) Kesinlikle Katılıyorum 
Ancak, forma yansıtırken bu sıralamayı sondan başa doğru yapmak cevaplayanın kolaylıkla takip etmesi açısından daha uygundur. Okullardaki eski not sisteminde 5 en iyi, 1 de en kötü not olarak kullanıldığından en olumlu kanaati 5 ile en olumsuz kanaati de 1 ile karşılamak makuldür.

Şekil 5: 360 Derece Performans Değerlendirme Formu- Önerilen Belirtme Çizelgesi

\begin{tabular}{|c|c|c|c|c|}
\hline \multicolumn{5}{|c|}{ ÖNERİLEN BELİRTME ÇİZELGESİ } \\
\hline $\begin{array}{l}\text { Kesinlikle } \\
\text { Katılıyorum }\end{array}$ & Katıliyorum & $\begin{array}{l}\text { Kismen } \\
\text { Katılıyorum }\end{array}$ & Katılmıyorum & $\begin{array}{l}\text { Kesinlikle } \\
\text { Katılmıyorum }\end{array}$ \\
\hline 5 & 4 & 3 & 2 & 1 \\
\hline
\end{tabular}

360 Derece Gönüllü Performans Değerlendirme Modeli'nde gönüllü kuruluşların performansının ölçülmesi; güdüleme, öz gelişimi sağlama, uygulama, ölçme, teknik beceri, kişisel bütünlük, genel liderlik profili gibi yedi başlık altında yöneltilen 38 soru ile gerçekleştirilmektedir:

Şekil 6: 360 Derece Performans Değerlendirme Formu-Gövde

\begin{tabular}{|c|c|c|c|c|c|}
\hline I- GÜDÜLEME & 5 & 4 & 3 & 2 & 1 \\
\hline 1- Gönüllünün isteklerini belirtmesine yardımcı olur & & & & & \\
\hline 2- Verimli çalışan gönüllüyü ödüllendirir & & & & & \\
\hline 3- Gönüllüyü en iyi şekilde çalışması için motive eder & & & & & \\
\hline 4- Gönüllü çalışanlara yardım eder & & & & & \\
\hline II- ÖZ GELİŞİMİ SAĞLAMA & & & & & \\
\hline 5- Gönüllünün mesleki gelişimine yardımcı olur & & & & & \\
\hline 6- Kurumda eğitimler düzenler & & & & & \\
\hline 7- Örnek kişilik sunar & & & & & \\
\hline
\end{tabular}


Fethi GÜNGÖR

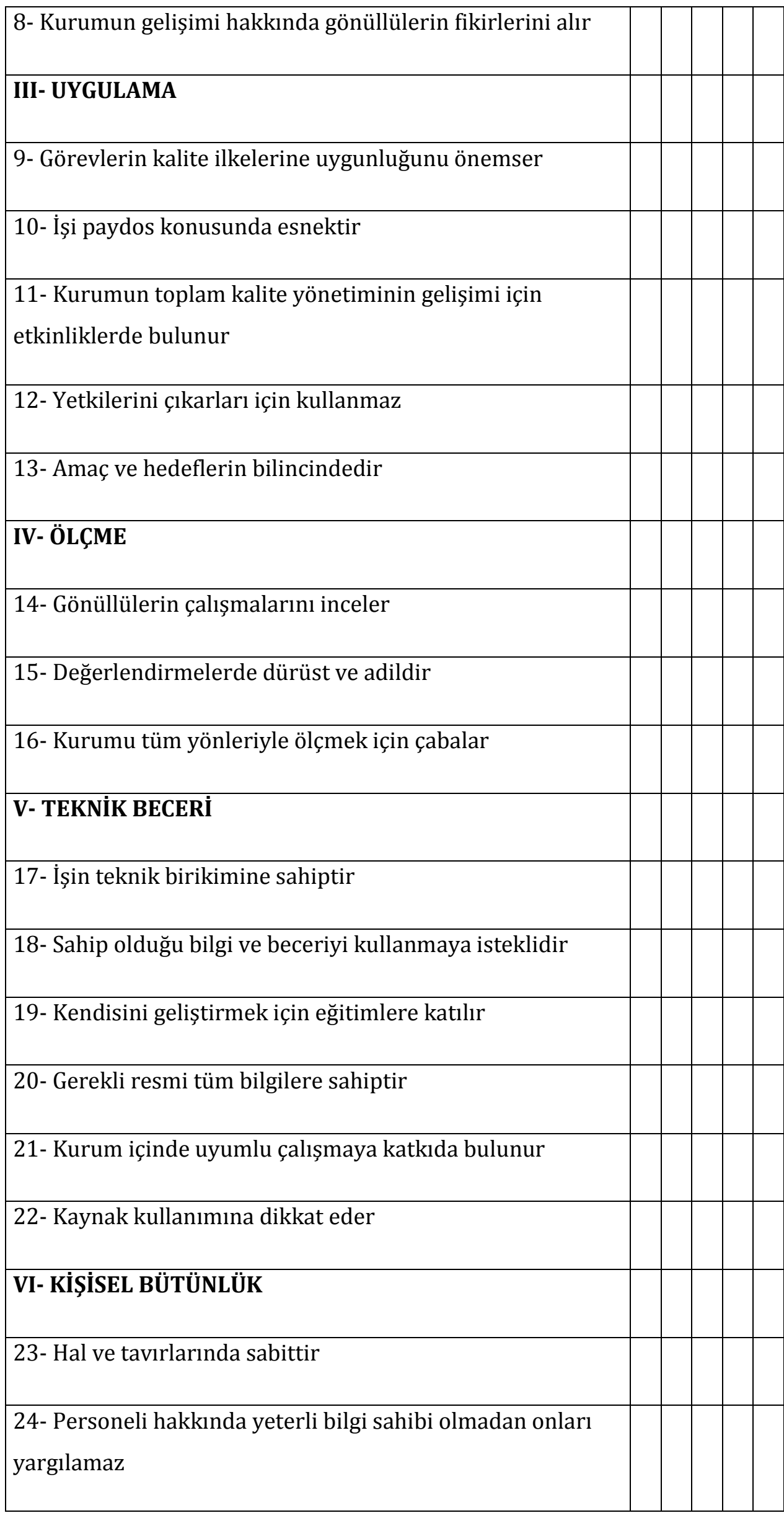


Strategic Public Management Journal (SPMJ), Issue No: 4, pp. 21-48

\begin{tabular}{|c|}
\hline 25- Dürüstlük ve içtenlik onun için önemlidir \\
\hline 26- Kibar ve saygındır \\
\hline 27- Edaları, tavırları ve çalışmalarıyla örnek olur \\
\hline 28- Kimseyi kayırmaz, herkese adil imkânlar sunar \\
\hline 29- Özel hayatını işine yansıtmaz \\
\hline 30- Kendisine anlatılanları önemser \\
\hline VII- GENEL LİDERLİK PROFİLİ \\
\hline 31- Davranışları itimat vermektedir \\
\hline 32- Kurumun gelișimi için ileriyi görmektedir \\
\hline 33- Kişilik sahibidir ve davranışları tutarlıdır \\
\hline 34- Öğrenmeyi ve öğretmeyi önemser \\
\hline $\begin{array}{l}\text { 35- Kurumun hedef ve amaçlarına ulaşması için yol ve } \\
\text { yöntem belirlemeye katkı yapar }\end{array}$ \\
\hline 36- Herhangi bir konuda gönüllünün görüşlerine önem verir \\
\hline 37- Grup çalıșmasına önem verir \\
\hline 38- Problem çözme becerisine sahiptir \\
\hline
\end{tabular}

Yer yer müdahalelerde bulunarak STK'larda uygulanabilmek üzere uyarladığımız bu cetvel, gönüllü kuruluşun ihtiyaçları doğrultusunda kısaltılarak ya da uzatılarak uygulanabilir.

\section{Sonuç ve Öneriler}

Toplumumuzda nitelik ve nicelik bakımından sürekli artış gösteren gönüllü kuruluşlarda faaliyet yürüten gönüllü kişilerin bu gönüllü faaliyetleri sonucunda 
değerlendirilip mükâfatlandırılması, gönüllülerin motivasyonunu yükseltmek, onların bilgi, beceri ve yeteneklerinden yararlanmak ve hiçbir maddi çıkarı olmadan hayır işlerine destek veren duyarlı insanların performansını adil olarak değerlendirmeye elverişli bir model geliştirmek gerekmektedir.

Sivil toplum kuruluşlarının sayılarının artması ve kurumsallaşması ile birlikte, kaliteli bir gönüllü yönetimi mecburiyet halini almıștır. Gönüllü yönetimi ile birlikte sivil toplum kuruluşları daha kontrollü, hedeflerine ulaşmada daha aktif ve daha etkili kuruluşlar olacaklardır. Bu açıdan sivil toplum kuruluşları etkili bir planlama ile verimli bir gönüllü yönetimi süreci oluşturmalıdır. $\mathrm{Bu}$ süreç esnasında gönüllüler yakından değerlendirilmeli ve onların istekleri göz önünde tutularak uygun faaliyete daha donanımlı bir şekilde yönlendirilmeleri sağlanmalıdır.

Gönüllülerin kuruma olan bağlılıklarını arttırmak, hizmetlerini kaliteli bir şekilde gerçekleștirmek ve STK içerisindeki performanslarını arttırmak açısından değerlendirme oldukça önemlidir. Kuruma gönül bağı ile bağlanan gönüllülerin istekliliklerinin arttırılması ve samimiyetlerinin suiistimal edilmemesi, gönüllü yönetimi aşamalarına dikkat edilmesi ve son aşamada performansları değerlendirilerek ödüllendirilmeleri gerekmektedir.

Ülkemizde hala gönüllü kuruluşların büyük çoğunluğu gönüllü yönetimini vakit ve kaynak israfı olarak görebilmekte ve bu yüzden de gönüllü yönetiminin aşamalarına özen gösterilmemekte, kuruluşta gönüllü yöneticisi istihdam edilmemektedir. $\mathrm{Bu}$ çekimser tutum, gönüllü yönetimi süreci sonrasında kuruluşun elde edeceği katma değeri görememesinden kaynaklanmaktadır.

Sonuç olarak toplumsal fayda sağlamayı amaçlayan sivil toplum kuruluşlarının hedeflerine ulaşabilmesi, kaliteli bir hizmet sunabilmesi ve sürdürülebilirliğini sağlaması için sahip olduğu gönüllü kaynağa azami ölçüde özen göstermesi ve gönüllü kaynağın kuruluşa olan bağlılığını artırmak ve daha etkili çalışmasını sağlamak adına gönüllü yönetimi sürecini profesyonel bir şekilde gerçekleştirmesi, son aşamada performans değerlendirme çalışmasını gerçekleştirerek gönüllüleri ödüllendirmesi gerekmektedir. 
Kaynakça:

- AFL Club Management Program (2004), Volunteer Management for Football Clubs, Australian Football League, Australia.

- Akatay, Ayten (2008), Gönüllü Kuruluşların İnsan Kaynakları Sorunlarına Eğitsel Bir Çözüm, Çanakkale Onsekiz Mart Üniversitesi Girişimcilik ve Kalkınma Dergisi, Cilt: 3, Sayı: 1, 115-137.

- Argüden, Yılmaz ve Ilgaz, Pınar (2006), Gönüllü Kuruluşların Yönetimi, ARGE Danışmanlık Yayınları, 1. Basım, İstanbul.

- Bayram, Levent. (2005). Geleneksel Performans Değerlendirme Yöntemlerine Yeni Bir Alternatif: 360 Derece Performans Değerlendirme". Sayıştay Dergisi, sayı: 62, Ankara, s.47-65.

- Camgöz, S.M. ve Alptekin, İ.N. (2006). “360 Derece Performans Değerlendirme ve Geri Bildirim: Bir Üniversite Mediko Sosyal Merkezi Birim Amirlerinin Yönetsel Yetkinliklerini Değerlendirilmesi Üzerine Pilot Uygulama Örneği”

- Citizens Information Board, 2008: Managing Volunteers: A Good Practice Guide, http://www.citizensinformationboard.ie/publications/providers/ downloads/Managing Volunteers 08.pdf,(Erişim Tarihi: 25.12.2012)

- Coşkun, Ali (2006), STK'ların Stratejik Performans Yönetiminde Yeni Bir Yaklaşım: Performans Karnesi, Sivil Toplum, 4 (15), s.103-117.

- Coşkun, Ali (2008), Sivil Toplum Kuruluşlarında Yönetim, Seçkin Yayıncılık, 1. Baskı, İstanbul.

- DDB (Dernekler Dairesi Başkanlığı). (2015). http://www.dernekler.gov.tr

- EDAM. (2003). “Gönüllülük Psikolojisi ve Gönüllü Yönetimi”, Sivil Toplum Dergisi, Yll 1, Sayı 2, (Nisan-Mayıs-Haziran 2003).

- Flood, Joseph P., Eric Gardner, Kelvin Yarrell. (2005). “Managing Volunteers: Developing and Implementing an Effective Program", Proceedings of the 2005 Notheastern Recreation Research Symposium, April 10-12, New York, 80-88.

- Güder, Nafiz. (2006), STK'lar İçin Gönüllülük ve Gönüllü Yönetimi Rehberi, Sivil Toplum Geliştirme Merkezi, Ankara.

- Kadıköy Belediyesi. (2015). http://insanca.kadikoy.bel.tr/gonullu programi geliștirmek.html

- Özden, Kemal. (2008), Sivil Toplum Kuruluşlarında Gönüllü Yönetimi, Sivil Toplum Kuruluşlarında Yönetim, Ed. Ali Coşkun, Seçkin Yayıncılık, İstanbul. 
- Özmutaf, M. Nezih. (2007). “Sivil Toplum Kuruluşlarının Misyonlarını Gerçekleștirmede İnsan Kaynaklarının Rolünün Gönüllü Yönetimi Yaklaşımları Bağlamında İncelenmesi”, Süleyman Demirel Üniversitesi, Sosyal Bilimler Enstitüsü, İşletme Anabilim Dalı, Doktora Tezi, Isparta.

- Palabıyık, Hamit (2011), Gönüllülük ve Yerel Hizmetlere Gönüllü Katılım Üzerine Açıllamalar, Yönetim Bilimleri Dergisi, 9(1), s.82-113.

- Sarıkaya, Muammer (2011), “Gönüllü Yönetimi”, Sosyal Hizmet Kurumlarında Yönetim, Nobel Akademik Yayıncılık, 1. Basım, Ankara.

- Serbest P., Menekşe (2003). “Kurumsal Gönüllülük ve İnsan Kaynakları Yönetimi İlişkisi”, İstanbul Üniversitesi, Sosyal Bilimler Enstitüsü, Çalışma Ekonomisi ve Endüstri İlişskileri Anabilim Dalı, Endüstri İlişkileri ve İnsan Kaynakları Bilim Dalı, Yüksek Lisans Tezi, İstanbul.

- Vinson, M.N. (1996). The Pros and Cos Of 360-Degree Feedback: Making it Work. Training \& Development, 50 (4), 11-12.

- Yaman, Yılmaz (2005), Gönüllülük Psikolojisi ve Gönüllü Yönetimi, Sivil Toplum Kuruluşları İçin Yönetim Rehberi, Kaknüs Yayınları, 1. Basım, İstanbul.

- Yüce, P. (2003). 360 Derece Değerlendirme, Düşünceden Sonuca İnsan Kaynakları. İstanbul: Hayat Yayıncıllk. 